\title{
THE MORE THINGS CHANGE Continuity and Change in the American Racial Landscape
}

\author{
Michael C. Dawson \\ Department of Political Science, University of Chicago \\ Lawrence D. Bobo \\ Department of Sociology, Stanford University
}

Within the last eighteen months we have seen both the Katrina disaster and the Obama candidacy for the Democratic Party's nomination for president reshape the political landscape within the United States. Equally important, for our analytical purposes, both phenomena are strong indicators of the evolving nature of the American racial order. The Obama candidacy points to important changes in the racial terrain within the United States. His candidacy highlights the more tolerant nature of public racial discourse in the United States-it was not very long ago when a Black candidate for president was considered unelectable. Obama's candidacy also highlights how immigration from non-European countries has fundamentally reshaped the racial landscape. Obama is, of course, not the "traditional" Black candidate, as his African heritage is due to recent immigration, not the slave trade. Relatedly, his candidacy also highlights the evolving nature of, and contestation over, racial categories. Over the past decade we have seen similar processes transforming conceptualizations/categories such as Hispanic, Latino/a, and Asian American. With even more recent waves of immigration from Africa and the African diaspora, we are now seeing the category Black under heavy contestation-which was brought to the (White) public eye as a result of the furor over whether Obama is "Black" enough to garner African American support and whether (as Senator Joseph Biden implied) part of Obama's crossover appeal is the perceived absence of a "tainted" African American cultural heritage. The Obama candidacy is emblematic of one type of change that marks the American racial landscape.

The Katrina disaster, on the other hand, to which we dedicated our entire last issue, was more indicative of continuities in the American racial order. As many of the articles in that issue detailed, the aftermath of Katrina highlighted how the intersection of race, class, and gender continues to place African Americans in a subordinate position within the American racial hierarchy, leaving them not only 
disproportionately vulnerable to "natural" and man-made disasters, but also largely excluded from White-dominated civil society as well as the publics which are critical to influencing opinion formation and policymaking. As sociologists Jennifer Lee and Frank Bean, among others, have argued, while there is substantial dynamism within the racial order, with increased immigration over the past few decades, as well as other trends, Blacks and Whites still largely anchor the two ends of the hierarchy in terms of opinion, material circumstances, levels of residential segregation, and interracial intimacy. Yet the Katrina disaster also highlighted the importance of the changes in the racial order. One often overlooked aspect to the aftermath of the disaster, for example, was the flow of tens of thousands of Latino workers into the New Orleans area for work. The conditions and wages that these workers are experiencing denote yet another moral and material tragedy at the intersection of race and class.

Several of the articles in this issue of the $D u$ Bois Review demonstrate various aspects of continuity and change in the American racial order. Our lead article, Mazzocco et al.'s "The Cost of Being Black," highlights the deepness of the change in White perceptions of Black racial disadvantage. We know from survey results that two-thirds of White Americans over the past decade believed that Blacks either have achieved or will soon achieve racial equality in the United States. Through a series of experiments, Mazzocco and his colleagues show the cognitive foundations for that response. They find that most Whites say that they would be willing to switch to being Black for less than $\$ 10,000$ (for reference, the authors found that the same subjects would on average want a million dollars to give up television). Not surprisingly, the authors find a correlation between how much subjects assign to the cost of being Black and their support for reparations. The lower the perceived cost of being Black, the lower the support for reparations. As the authors state, "fundamental biases in estimating the true cost of being Black" undermine the possibility of even having a discussion about the pros and cons of reparations.

Altman and Klinkner's "Measuring the Difference between White Voting and Polling on Interracial Marriage" shows, however, that whatever many Whites' perceptions may be, and statements are, about Blacks having achieved racial equality, their actions often suggest quite a different story. Their analysis shows that White voters in Alabama (and slightly less so in South Carolina) voted in substantial numbers to keep on the books antimiscegenation laws, even though they had only largely symbolic effects. As many as $50 \%$ of White Alabamians supported keeping the statute ( $40 \%$ in South Carolina). Regardless of professions of racial tolerance and confidence about the prospects for racial equality, large numbers of Whites still disapprove of interracial intimacy and relationships. This phenomenon marks a strong connection to past White attitudes on Black/White relationships, even if such relationships do not suffer from violent attacks at the same rate as they did during most of the twentieth century. Twine and Steinbugler's "The Gap between Whites and Whiteness" explores interracial intimacy from quite a different angle. Their discussion focuses on how families adjust, and particularly on strategies that White parents develop to cope with the challenges that interracial relationships and families must constantly face. Hero and Preuhs's article examines how state agencies cope with the changing racial divide and note that a preexisting egalitarian tradition within a state is correlated with states having more progressive civil rights policies. Their article demonstrates the linkage between continuity and change in the sense that the ability to be more inclusive in the face of rapidly changing racial demographics is rooted in the struggles of the past.

One of the liveliest and longest standing ongoing debates among scholars on race is about the tensions many scholars in this field experience between being an "objec- 
tive," "neutral" scholar committed to the highest standards of intellectual rigor, on the one hand, and being a committed scholar whose work contributes to achieving justice, on the other. Two of our articles, those by Robert Williams and Barrington Edwards, explore these tensions in one of the richest possible arenas - the work of the scholar after whom this journal is named: W. E. B. Du Bois. Williams focuses on some of Du Bois's early research in order to extract the latter's views on the philosophy of science, the need to be both rigorous at the highest level and produce scholarship that aids the cause of achieving racial justice, and, more generally, the importance of producing "scientific truth" as a weapon to be utilized by "politically engaged" scholars. Edwards explores similar philosophical dilemmas-concentrating on how Du Bois utilized different voices when operating as a "race man" versus as a social scientist marginalized for both his race and his intellectual perspectives. Williams's and Edwards's essays serve to remind us of the importance for room to be made for scholars who are both rigorous and engaged. Both articles also suggest how much has been lost due to the overspecialization and narrowness of our current academic disciplines. Du Bois's career would be very nearly impossible to duplicate just on the basis that it is extraordinarily rare for scholars to be trained today with the breadth to enable them to make important professional contributions in multiple disciplines; in Du Bois's case, these included philosophy, history, and sociology.

One weakness in Du Bois's scholarly analysis and political practice was in the area of gender. Another one of the longest standing and most contentious fields of studies within racial studies, especially Black studies, has been the study of the relationship between Black men and Black women. Even more contentious have been scholarship and arguments that purport to analyze how African Americans view interracial relationships. This issue's third take on interracial relationships is found in the lively debate within our symposium section. The focus of the articles by Jeffries, Childs, and Morgan and Bennett is an evaluation of Black women's purported view on Black male/White woman relationships. These authors debate to what degree Black women are "angry" about such relationships, and to the degree that they are (the authors do not agree on whether Black women are angry in the first place), what explains the anger and what one's normative stance toward that anger should be. Morgan and Bennett exhort those who study Black women to move beyond the acceptance of stereotypes said to capture Black women's behavior and attitudes, and to guard against arguments that oversimplify the nuanced and highly contextualized milieu which constitutes "Black women's actual emotional experience" (emphasis in the original). In her essay, Takara offers a unique glimpse into the world of the Black female academic, reminding us of the implications that Black women's marginalized position within the academy has for the development of their professional careers. Sadly, perceived inferiority, what political scientist David Greenstone nearly forty years ago labeled imputation inferiority, continues to plague Black women and men in a vast array of professional, political, and social arenas.

Our book review essay section also treats the themes of continuities and change in the racial environment within the United States. John Jackson, in a review of books that study how the concept of race is taught in the schools, notes that "race is doing some very strange things these days." He goes on to describe the "surreal social context" within which young people must navigate the terrain of race while their elders deny the powerful impact that race has on a wide portion of their lives. Jackson argues, and we agree, that there are deep costs to not talking about or teaching about race within our schools, or doing so poorly.

Francis Abiola Irele's review celebrates the growth of Africana studies and reviews books that have a wider geographic scope in the study of such central topics as the 
effect of slavery on Africa and the development of transnational Black identities. While Irele is correct in lauding developments within Africana studies, it is nonetheless the case that works within the self-described fields of Black studies, African studies, and Afro-American studies-as well as Africana studies-too often are not in conversation with one another, and thus perspectives and findings in one of these domains are often not known, considered, critiqued, and reformulated within the other domains. There are also political stakes in how these domains view themselves and each other. On a larger scale, the politics of diaspora played out in the pages of the November 1969 issue of The Black Scholar, where then President of Senegal Léopold Sédar Senghor and then President of Guinea Sékou Touré debated the validity of concepts such as Négritude (and, by implication, other diasporic-wide cultural identities and movements) rather than concentrating on the political and material liberation of African people within the boundaries of specific nation-states. Today these debates remain with us, as many scholars increasingly argue for the necessity of having a much wider geographical and cultural scope when studying populations of Africa-descended people (often with the at least implicit view that national boundaries and the nation-state have always been overemphasized within Black studies and make increasingly less sense as political and intellectual limits for today's inquiries). Other scholars argue that the "death" of the nation-state has itself been greatly exaggerated and that, given the diversity of experiences, it still makes the most sense for most research to focus on populations of Africa-descended people within particular nation-states. While the specifics of this debate have changed with global and national changes in racial environments, this is another of the longstanding debates within Black studies. We should note that this is not a debate confined to the academy, but was also a central aspect of the dispute between the Black Panther Party and Stokely Carmichael's (who changed his name to Kwame Toure) followers in the late 1960s and early 1970s.

Finally, Victor Thompson reviews books that detail the growth of the multiracial movement (the movement that, among other things, lobbied for the "mark one or more" option in the 2000 U.S. Census), bringing us back to how the changing racial terrain in one domain (the increased visibility of multiracial families) can reshape the racial terrain in another domain (in this case, the politics of race). The growing multiracial movement produced unusual political alliances between groups as diverse as liberal soccer moms (the mothers of interracial children-and the key agents in building the movement, according to the books that Thompson reviews) and rightwing politicians with a history of hostility toward civil rights. Thompson does criticize the works for not generally connecting the field of multiracial studies more directly and theoretically to the general field of racial studies.

While this issue offers a wide range of articles on continuities and changes in America's racial landscape, the next issue of the $D u$ Bois Review will offer a much more focused look at a phenomenon that has radically reshaped this terrain: immigration.

Corresponding author: Professor Michael C. Dawson, Department of Political Science, 419 Pick Hall, University of Chicago, Chicago, IL 60637. E-mail: mc-dawson@uchicago.edu 